\title{
Understanding political ecologies of land use change using household surveys in Mankweng, South Africa
}

Joshua Edward Rutkowski

West Virginia University

Follow this and additional works at: https://researchrepository.wvu.edu/etd

\section{Recommended Citation}

Rutkowski, Joshua Edward, "Understanding political ecologies of land use change using household surveys in Mankweng, South Africa" (2006). Graduate Theses, Dissertations, and Problem Reports. 759. https://researchrepository.wvu.edu/etd/759

This Thesis is protected by copyright and/or related rights. It has been brought to you by the The Research Repository @ WVU with permission from the rights-holder(s). You are free to use this Thesis in any way that is permitted by the copyright and related rights legislation that applies to your use. For other uses you must obtain permission from the rights-holder(s) directly, unless additional rights are indicated by a Creative Commons license in the record and/ or on the work itself. This Thesis has been accepted for inclusion in WVU Graduate Theses, Dissertations, and Problem Reports collection by an authorized administrator of The Research Repository @ WVU. For more information, please contact researchrepository@mail.wvu.edu. 
Understanding Political Ecologies of Land Use Change using Household Surveys in Mankweng, South Africa

\title{
Joshua Edward Rutkowski
}

Thesis submitted to

The Eberly College of Arts and Sciences

At West Virginia University

In partial fulfillment of the requirements

For the degree of

\author{
Master of Arts \\ in \\ Geography
}

Robert Q. Hanham, Ph.D.

Brent McCusker, Ph.D., Chair

Jennifer Miller, Ph.D.

Department of Geology and Geography

Morgantown, West Virginia

2006

Keywords: Land Use Change, South Africa, Household Survey, Limpopo 


\begin{abstract}
$\underline{\text { Abstract }}$
Understanding Political Ecologies of Land Use Change using Household Surveys in Mankweng, South Africa
\end{abstract}

\author{
Joshua Edward Rutkowski
}

Mankweng, Limpopo, South Africa has experienced a large population growth since its inception in the late 1950s. The impacts of land use changes in the area are far reaching and have a wide range of influences. This paper documents the historical and political pressures affecting Mankweng as the township progresses into the $21^{\text {st }}$ Century. Household surveys were conducted in 2005 and 2006 in order to understand the geographic relationships of the area. This study found household surveys to be beneficial in understanding land use change. 


\section{Acknowledgements}

I would like to thank several people and offices for their support and funding of this thesis. Most importantly I would like to thank my thesis advisor, Dr. Brent McCusker for his continuing support both in the United States and in South Africa. He supplied me with the tools and background to succeed in this endeavor; none of this would be reality without him. My other committee members, Dr. Robert Hanham and Dr. Jennifer Miller have also been invaluable in this process providing detailed responses to my questions and revisions to this thesis.

Three offices supported my overseas research. West Virginia University's Department of Geology and Geography, Office of International Programs, and the Eberly School of Arts and Sciences provided necessary financial support. In addition I would to thank the staff at the West Virginia GIS Technical Center for their help in map production.

My family, always encouraging, is the root of why I am able to succeed in life. I would like to thank them all. Carmen has the amazing ability to read numerous drafts of this thesis without complaint and holds an undying support for me and my pursuits. My Mother and Father created a foundation of learning since my childhood that has permitted me to continue to grow. Abram has taught me more than he realizes. David and Leslie continually support my endeavors and supply a creative dialogue about the Academy. Finally, Maureen, who was only able to see me through half of this degree, will always be remembered.

Many fellow graduate students supported my work through personal and classroom discourse. In particular I would like to thank Eric Hopkins for his support of my field studies (including his permission to let me leave my research obligation at the GIS Tech Center), Franklin Graham for his blunt and truthful commentary on African conditions and Tim Hawthorne for his guidance and suggestions. 
Abstract

Acknowledgements

iii

Table of Contents

iv

List of Figures

List of Appendices

Introduction

Section 1: Literature review

1.1: Political Ecology

1.2: Land Use and Cover Change Studies

1.3: Synthesis of Literature Review

Section 2: Historical Context of Land Use in South Africa 9

2.1: Bantustans/Homelands

2.2 :1994 Democratic Elections to Present

2.3: Land reform initiatives in late 90's to present 12

Section 3: Mankweng

3.1: Geography of Mankweng

3.2: Household Information

3.3: Land Use

3.4: University of Limpopo $\quad 20$

Section 4: Methods

4.1: Household Interviews

4.2: Sampling Framework

4.3: Government Reports

4.4: University of Limpopo Libraries

Section 5: Data Analysis and findings

5.1: Data Analysis and Findings

5.2 Recommendations

Section 6: Summary and Conclusion 
List of Figures and Tables

Figures

Page

Figure 1: Map of Limpopo Province

Figure 2: 2001 census data for Mankweng

Figure 3: 2001 census data for Mankweng

19

Figure 4: University of the North in 1963

Figure 5: Mankweng housing

Figure 6: Government sign

Figure 7: Provincial sign

Table

Table 1: Post-classification household analysis of the Mankweng Area 
List of Appendices

Appendix A Respondent Handout

Appendix B Exemption of Institutional Review Board 


\section{Introduction}

Southern Africa represents a melting pot of ideas, histories and futures. The complex reality in this part of the world may be investigated using many different research paradigms. The methodologies of investigation may produce different levels of understanding. South African land use has been documented throughout the major eras of the Republic's history: the pre-colonization period, the colonial period, the Apartheid government and finally the present post-Apartheid government. Policy from each of these time periods affects the current situation of land use in South Africa differently but all are manifest in current land use. Lahiff explains how "high rates of unemployment, poor returns to small-scale agriculture, lack of access to social services such as health and education, recurring drought and a rampant (and largely unaddressed) HIV/AIDS pandemic serve to erode existing livelihood activities and perpetuate relative and absolute poverty in rural areas [of Southern Africa]” (Lahiff 2003: 2). While many studies document land use in the metropolitan parts of South Africa, i.e. Cape Town, Durban and the Tshwane/Johannesburg metropolis, less research has been conducted on the interactions of people and the environment further away from these economic centers. Rural areas often undergo radical transformations through time as livelihoods are affected by national politics. Mankweng, in the Limpopo Province, has drastically increased in size since it was established in the late 1950s. The implications of this growth can be seen throughout the Mankweng region, for example: congested taxi areas, overcrowded marketplaces and continuing construction.

This paper documents the way local and national pressures continue to produce growth in Mankweng. The implications of growth are far reaching and consequently must be illustrated in order to be addressed. Household interviews and archival research are used in this study to understand the rapid growth of Mankweng. Respondents of the survey offer keen insights into the land use dynamics at play within Mankweng; their comments are included throughout this paper and offer commentary related to land use change.

Political ecology and land use change studies are utilized in this paper and both are reviewed in Section one. Geographic investigations using the political ecology framework enable understanding of the interaction between the environment and humans by examining influences at different scales. Land use change studies are enhanced through historical 
understanding and documentation; Section two recounts the historical context of Mankweng and also documents the germane laws of South Africa. Section three details the geography of Mankweng. The methods of investigation are explained in Section four. Finally, Section five includes recommendations to the area.

The key research questions here include: How long have households in Mankweng been living in the township? Why did they move to Mankweng? Are the services they receive in Mankweng adequate for their needs?

In this thesis, household survey data will be presented. These surveys were conducted by the author in late 2005 and early 2006. Previous studies of the area (including SAR Census data) do not address the gap between land use change evidence and any specific consequence. The findings of this research work towards filling this void. Results show the inherent spatial context of political decisions related to land use change. The Mankweng area reveals complex political relationships that cannot be disconnected from the increasing population of the area. This paper supports the geographic relevance of using a political ecology framework in land use studies. 


\section{Section 1: Literature Review}

\section{Section 1.1: Political Ecology}

The burgeoning research of political ecology in the 1990's spanned the globe with primary focus in Africa, Asia and South America. Ben Page explains that political ecology is usually defined under five different definitions/traditions (Page 2003). Included in these definitions/traditions are:

1. Although now rarely used, this definition applies to political science whereby the 'ecology' is used as a "metaphor for understanding human politics” (358).

2. Political ecology to mean the political aspect of the environmental movement.

3. Political ecology to represent the argument that ecologists were inherently political in their research topics and methodologies. This definition applies to a criticism within ecology that contends ecologist's tendency to use the scientific method as the major justification to deny political existence within their research community. This derogatory term implied ecologists were in fact politically situated but would not recognize their position due to their entrenchment in the beliefs of the scientific method.

4. A definition of political ecology materialized in the 1970's economic anthropology literature as an attempt to understand the "relationships between the physical environment, production, resource ownership and the distribution of people” (358). Presently, many political ecologists, using this definition of political ecology, have intentionally denied the use of ecology studies in their research in order to emphasize the dominating power of politics in humannature interaction.

5. In order to better understand the relationship between phenomena of humanenvironmental processes, political ecology is framed here to "analyse environmental problems... between science and politics” (359). This tradition seeks to understand the interplay between policy (politics) and ecological research (science).

While these definitions/traditions, especially the latter three, may appear incongruent, Page asserts the "traditions of political ecology are intertwined, but distinct. The tension between 
them is the force that keeps political ecology lively...” (359). Major themes within geography including: politics, ecology, livelihood studies, land use change studies and geographic information systems are able to be investigated using a political ecology framework. This section outlines the ways in which political ecology can be used in these studies.

Stott and Sullivan contend that political ecology can now be credited with revealing the depth and complexity of "political dimensions of environmental narratives” (Stott and Sullivan 2000: 5). Political ecology goes beyond the regular investigative tools used by ecologists and cultural geographers alike. Robbins explains that political ecology looks toward the root of problems rather than explaining or teasing out the symptoms (Robbins 2004).

Bryant and Bailey explain how the use of political ecology facilitates the understanding of environmental issues; that these issues are based on complex political and economic forces and that these forces must change at multiple levels in order for the environmental problem to be resolved or ameliorated (Bryant and Bailey 1997).

One of the main thrusts of political ecology is multiple scale analysis. The scale of research in political ecology is understood to be interconnected with other scales of study. Agents or actors influence the local, regional and international arenas. Warren et al. maintain that the possibility of including all the scales as called for by Piers Blakie’s 1985 landmark book: The Political Economy of Soil Erosion in Developing Countries cannot be undertaken due to complexity and unavoidable unequal weighting of these scales in analysis (Warren, et al. 2000). Peet and Watts confirm political ecologist's current inability to work towards real solutions using the complex structures revealed within political ecology case studies (Peet and Watts 1996). Indeed, Blaikie explains that few political ecology researchers have provided exhaustive analysis of politics, power and the actors involved in the issues (Blaikie 1999). Lambin reinforces this notion of scale by recommending that research potential is best fitted according to proper scale (Lambin 2003). Investigations framed in political ecology can fail to notice “everyday preoccupations of the individual or small household” when trying to understand the causations and to effect environmental damages at larger scale than the household, e.g. large scale soil erosion (Warren, et al. 2000: 85). While political ecology studies typically try to incorporate all scales certain research data might only apply to specific levels.

The framework of political ecology is too expansive to be covered in a single investigation. Moreover, the outlook that political dimensions must exist in geographic research 
leads to "question-begging research" (Vayda and Walters 1999) where the researcher assumes the importance of politics before any research has been undertaken. This critique poses a serious question to geographers using the political ecology framework. By outlining the failure of researchers in the past to understand the influences of politics in environmental problems, Bryant explains why politics are foremost in political ecology research (Bryant 1998). In order to understand environmental degradation, Bryant says the political nature of the issue must be understood. Gray finds that perspective determines the answer to investigative questions and conclusions of a study depends on who you ask and at what scale that person is opinionating upon (Gray 1999).

Zimmerer explains how household-level analysis in cultural ecology (and subsequently political ecology) is under constant transformation (Zimmerer 2004). Household-level analysis is constantly reordering its methods as an influx of theories from other human-environment approaches is integrated. Batterbury uses the term bricolage to describe rural people's adaptation to varying economic forces (Batterbury 2001). The change from subsistence agriculture to income-based livelihoods requires the introduction of market practices, sojourning, cattle herding and other adaptations to cope with new economic pressures. Batterbury emphasizes the way livelihood systems affect the landscape and the landscape in turn affects livelihood systems and goes on to show how micro-economies and rural realities of resource use have strong influences on the landscape

Modern geospatial tools permit new questions to be asked and answered. Geographic Information Systems and Remote Sensing (GIS/RS) hold the potential for more quantitative analysis of political ecology research areas. GIS/RS are constrained, however, to snapshots of reality and must be included into a larger research framework. The resulting framework should be holistic reviews of the research area. Turner advocates the use of new geographic technologies with the understanding that "GIS/RS will not be the key tool for some researchers pursuing this larger vision of human ecological research, but for others GIS/RS could be.” (Turner 2003: 181). In another article, Turner explains how GIS/RS ought to be used to improve research "without losing the dynamic, structured, multilayered and subjective natures of socio-ecological interaction” (Turner 2003: 257). 


\section{Section 1.2: Land Use and Cover Change Studies}

Land use and cover change analysis plays an integral part in the efforts of science to create an accurate picture of the Earth and estimates on the future. Land use is the employment of land by humans. Without this scientific inquiry, decision makers lose a large part of the picture and would be forced to rely too heavily on other components of the decision-making process such as popular opinion, economics or political interest. Moreover, land use and cover change studies help to dispel incorrect ideas about planning and managing areas.

Fairchild and Leach explain how after providing local decision makers with their research, the decision makers were inclined to do more research and then change their planning paradigm to include the new information. The research by Fairhead and Leach used land use and cover change detection to challenge the popular notions of forest management in the Kissidougou region of Guinea (Fairchild and Leach, 1996). In this case, the most well-informed decisions were made when analysis of land use was included.

Without the land use perspective, research lacks spatial investigation and therefore lacks integrity. For example, Schroeder documents the disconnect that might occur when planners do not wholly account for each land use. In a specific instance, Schroeder explains how planners neglected local people when creating a wildlife reserve. He notes that many "proposed zoning systems have mainly comprised a disparate and disconnected chain of habitat islands...thus, an additional territorial allocation, the 'wildlife corridor', was created... which restricted human access to critical passages” (Schroeder 1999: 365). From this issue, land use analysis can extrapolate the necessary information to surmise potential answers for both human and wildlife. While interested parties face contending agendas, land use and cover change analysis broadens the understanding of what is actually occurring. Instead of relying on anecdotal or skewed information, land use and cover change studies achieve a conclusion by using objective materials such as aerial photographs and satellite imagery. Land use and cover change research holds the potential to explain trends by showing what has occurred in the past and how this has led to its current use or cover.

A study researching the Badia region of Jordan found human activities contributed to a devastating ecological and social effect on the landscape (Al-Bakri, et al., 2001). Similarly, other research has indicated how land use affects local cover change. Bouvier and Grant highlight how land use may persist but land cover may be affected and vice versa (Bouvier and 
Grant 1994). The authors explain that the National Park system in the United States remains relatively the same in size but has an increasing amount of visitors each year. In this way, land use remains the same but the effects on the environment can be devastating. Again, in the Badia region of Jordan, heirs of the land will desire agricultural fields to be located near roads causing irregularly shaped plots, which hinders the ability to use modern cultivating equipment and exacerbates soil erosion (Al-Bakri, et al., 2001: 260). In both of these instances, land use remains the same but negative consequences still result. Land use and cover change research holds the potential to explain trends by showing what has occurred in the past and how this has led to its current use or coverUSED THE SAME SENTENCE IN LAST LINE OF ABOVE PARAGRAPH, CHANGE WORDING!. In many cases, this research and the resulting data suggest more positive alternatives to the circumstances. Although the National Park system in the U.S. has not dealt with the issues at hand, the Jordanian government has considered the issues in the Badia region and is attempting to apply land use and cover change research to further sustainable practices in the area. When it becomes impossible for the U.S. National Park system to ignore its own inevitable changes, land use and cover change information will be an invaluable resource in searching for solutions.

Land use and land cover change analysis enhances research as more remote sensing data is available to geographic researchers. However the application of land use and cover change studies to social science creates a suite of issues. There are many different ways to apply remote sensing in the social sciences. Although the use of remote sensing has been used in the past half century, the application to social science has only recently become widespread. Recent technologies in remote sensing, including better software and higher resolution datasets, allow remotely sensed data to be used in many social sciences- from demography to anthropology to geography (Rindfuss and Stern, 1998). Presently, household level data may be integrated into a larger research endeavor. Lambin outlines two studies in Africa where household studies are the crux of understanding land use change (Lambin, 2003). 


\section{Section 1.3: Synthesis of Literature Review}

Both political ecology and land use change studies are used to understand change through multiple scopes. In order to understand land use, one must incorporate social science. The political ecology paradigm can be used to document the historical and political dimensions of land use. Land use and cover change studies traditionally emphasize remote sensing data but in the past decade have increasingly used social science as a strong component in applied research. Moreover, Sussman et al. maintain the need for more imagery, more mapping and more ethnography of the area to ensure the accuracy of geographic studies (Sussman et al., 1994). The integration of political ecology research methods permits land use change studies to broaden and deepen the knowledge base necessary to holistically understanding land use. 


\section{Section 2: Historical Context of Land Use in South Africa}

\section{Section 2.1: Bantustans/Homelands}

White manipulation of African land use dates from before the Apartheid era. This section outlines the major legislative Acts passed by the South African government that affected land use. Many of the implications of these Acts were far reaching in the African community. Social, cultural and economic repercussions were felt as these laws were put into practice. As detailed below, both capital and power interests play a large role in the creation of African homelands.

The rising tide of the Apartheid government may be seen far before the National Party gained power in 1948. The Glen Grey Act of 1894 was implemented by Prime Minister of the Cape, Cecil Rhodes, to ensure an African labor force for the mining industry. The Act legislated the first control over African land rights by designating a limited role in government for Africans and a dominant role for whites (DR 2005). The 1913 Native Lands Act prohibited Africans from purchasing land outside designated reserve areas and laid legislative precedent for land control by the central government. Platsky and Walker explain how this Act relegated Africans to become renters and laborers by taking away their ability to own land (Platsky and Walker 1985). The low quality and small quantity of land available in reservations prevented Africans from prospering by farming or mining the land. Since economies were solely situated in white areas, Africans were forced into economic dependency, and became available to whites as a migrant labor force. In the 1930s, the South African government clarified the internal political struggle between white farmers and white industrialists about land allocation to Africans and in 1936 passed the Development Trust and Land Act which enlarged the reserve land area to 13\% of South Africa and legalized the eradication of "black spots” (Clark and Worger 2004: 22) “Black spots” are areas of African settlement within white farming areas. By 1936 over 70\% of the population was legally required to live in $13 \%$ of the land area.

In 1948, the National Party gained power in the South African government and codified apartheid in an effort to address the rising African political power and the increasing angst of whites over industrialization and urbanization. The opportunity to lean away from racial segregation existed at this time due to South Africa's growing economy. Instead, the National 
Party demanded more segregation and instituted harsher land restrictions. Indeed, Platsky and Walker explain the National Party's interest was to "preserve, strengthen and modernize the system of racial domination already in existence" (Platsky and Walker 1985). The 1951 Bantu Authority Act assigned tribal, regional and territorial authority power in the reservation area to traditional leaders. This allowed the National Party to manipulate the reservations behind the scenes by appointing the local African elite to these positions of power. If the local officials cooperated with the intentions of the National Party they would be rewarded by increases in salary, land and other benefits. However, should the local authorities become a nuisance; the National Party would appoint another person to their post.

The 1951 Bantu Authorities Act contained the term "homelands" which refers to the "reserves" created by the 1913 Natives Land Act. Both were legislative efforts to control nonwhite populations. The Commission of the Socio-economic Development of the Bantu areas within the Union of South Africa, hereafter referred to as the Tomlinson Commission, was appointed in 1954 to evaluate and make recommendations for the future of the Bantu reservations. The report consisted of 3,755 pages and was condensed to a summary for the public. The summary consists of 213 pages and 64 maps (U.G.61/1955 1955). The results of the report indicated the huge disparity between African population and access to land. The report highlighted the need for aerial expansion of the Bantu reserves as well as increased industrial investment in the areas. The Tomlinson Commission "had concluded in 1956 that the areas set aside for Africans would never, even under the best conditions, be able to support more than two-thirds of the African population" (Clark and Worger 2004). The report concludes: "the choice is clear: either the challenge must be accepted, or, the inevitable consequences of the integration of the Bantu and European population groups into a common society must be endured” (U.G.61/1955 1955). The National party did accept the recommendation that some industries locate themselves near the border of Bantu areas in order to utilize the African labor force but, overall neglected many of the commission's findings (Platsky and Walker 1985). The Promotion of Self-Government Act, enacted in 1959, detailed how "Bantu” areas were to become recognized by the South African government as independent nations. This act was accompanied during the late 1950's by other attempts to ostracize Africans from any legitimate redress or representation within the union government. By this time, mechanisms within the government were laying the foundation of separate nations. In 1970, the government 
was able to pass the Black Homeland Citizenship Act where Africans were to be citizens of a homeland and not citizens of South Africa. This Act contradicted itself though. First, most Africans did not live in homeland areas- this fact was largely recognized by the South African government. Furthermore, the South African government recognized the necessity of African labor within the South African economy and strategically placed portions of homelands near white population centers.

As detailed in later sections of this paper, the Mankweng area evidences many of the legacies and subsequent social implications of these Acts. While civil unrest is documented throughout the $20^{\text {th }}$ century, Clark and Worger point out: “the South African government turned increasingly to brute force...throughout the 1960's and 1970's, the government imprisoned all of the country’s most experienced African leaders, outlawed their organizations and prohibited all forms of protest against government policies” (Clark and Worger 2004: 62). The ingredients for a revolution were obvious and the government was attempting to thwart all attempts in last ditch, violent efforts which ultimately proved ineffective.

\section{Section 2.2: 1994 Democratic Elections to Present}

As detailed above, the Apartheid government of the National Party enacted many legal constraints on African citizens. Unrest within the African community became common by the late 1960s to mid 1980s. Land use change has an inherent political component that is essential to understand. Mankweng had a crucial role in African politics throughout the Apartheid era. University of Limpopo administrators claim the campus had many protests, especially in the 1980s. By the late 1980s, the African National Congress (ANC), banned by the National Party in 1960 after a demonstration turned deadly in Sharpeville, were recruiting and training South Africans in the neighboring countries of Botswana, Zimbabwe, Swaziland and Mozambique. Indeed, violent methods were occasionally employed by outlawed ANC members and murders of white political officials occurred occasionally in response to political events. International pressures about the injustices of the Apartheid policies meant the government was faced with fewer and fewer options. In 1962, the United Nations established the "United Nations Special Committee against Apartheid.” This became the center of efforts for international communities to organize governmental action against Apartheid. The many measures taken by the United 
Nations to bring about the downfall of the apartheid system ranged from an arms embargo to a convention against segregated sporting events. In 1992, to support the 1990 National Peace Accord, the Security Council deployed the United Nations Observer Mission in South Africa (UNOMSA). With 2,527 staff deployed around the country, the mission observed the April 1994 elections in which all South Africans were allowed to participate on an equal basis. The elections led to the establishment of a non-racial and democratic government. (http://www.unog.ch/80256EE600594458/(httpPages)/AAF20C17ADA889B5C1256F550058C1E4?OpenDocu ment. Last accessed on 3/19/2006)."

\section{Section 2.3: Land reform initiatives: Late $20^{\text {th }}$ Century to present}

Land reform initiatives frame land use change by restricting areas of growth and permitting new development sites. The capacity for people to move onto previously inaccessible land is made possible by land reform initiatives. This section highlights the major land reform policies of the 1990s to present.

Land ownership may be claimed as one of the root motivations for all governments instituted in South Africa. The "right" to land stood as one of the largest motivational points for rural Africans when the African National Congress was garnering support in the late 1980's and early 1990's. Lahiff argues that until the Zimbabwe farm invasions of 2000, little national attention was paid to land reform in South Africa (Lahiff 2003). After 2000, the general public realized the threat posed by civil unrest over land and the threat of a Zimbabwe style invasion prompted public dialogue on land reform. This section outlines the major plans implemented in the late twentieth century to present.

In 1994, the Restitution of Land Rights Act set forth legal support to compensate people who suffered land loss from 1913 to present due to racial discrimination. The 1994 Reconstruction and Development Program lays out three main goals for land reform: redistribution, restitution and land tenure. As detailed below, these three goals have met serious problems in implementation and accordingly have altered from their original plan. The African National Congress has yet to implement any radical land reform oriented toward poor rural Africans (Lahiff 2001). Instead, the reforms detailed throughout this section tend to focus on neo-liberal, market based land reform decisions which look toward macro economic successes. 
Narsiah documents how these new market forces negatively affect poor South Africans and indicates the need for the national government to address the situation (Narsiah 2002).

The African National Congress promised to transfer 30\% of white-owned land to Africans by 1999. By 2001, however, only 1\% of white-owned land had been transferred (Mather 2002). Explanations for this failed promise range from bureaucratic burdens, lack of proper plans in rural areas, political influences and a host of other issues. Lahiff highlights how this failure is a direct result of the ANC's neo-liberal economic policies because it "is based on respect for private property, reliance on market mechanisms, tightly controlled public spending and minimal intervention on the economy" (Lahiff 2001: 1). Manji claims that the "lack of political will, community conflicts and the actions of individual implementers are the most important factors which merit attention” to understanding why land reform implementation has not been successful (Manji 2001: 335). Claims that internal problems are the sole obstruction to massive land reform in South Africa undermines other important factors like national politics and international markets. National politics have a hand in most land reform acts and consequently mandate most policies using a top-down approach. International markets hold interest within South Africa and are able to influence decisions based on neo-liberal policies which stem from the South African national government.

Land tenure, the legitimate claim and ownership of property, is the core of land reform in South Africa. Both redistribution and restitution require a transformation of land tenure. Generally speaking, rural areas in South Africa are undergoing two types of land tenure reform: private ownership and public ownership.

May explains the goal of restitution, as mandated by the new national constitution, to “provide remedial options to people dispossessed by the past racially discriminatory legislation and practice” and is "likely to affect more than 500,000 households” (May 2000: 3). Land restitution is an attempt by the government to return land ownership from land obtained by whites during the colonial period to Africans who produce evidence that their family lived on the land prior to colonization (pre-1913). This formidable task is plagued with both political and logistical problems. The political problems arise from the intrinsic value of land for all parties interested. A national interest exists in maintaining productive, arable land. Lahiff and Scoones explain that "both restitution and redistribution of land have suffered from over-reliance on market mechanisms to acquire land and cumbersome and ineffective bureaucratic processes” and 
go on to say that the policy paradigm has shifted away from the "pro-poor [sic] approach" of the late 1990's and “towards a commercial farming model”(Lahiff and Scoones 2001:2) This shift from small farm to agri-business has serious consequences for land tenure. Logistical problems arose with the first attempt of the new government to redistribute land with the Settlement/Land Acquisition Grant (SLAG). SLAG offered R16,000 to poor, landless households so that the household could purchase land to farm. Since most farmlands were beyond the price tag of the individual grant (R16,000), households would band together into a Communal Property Association (CPA). Ntsebeza suggested the only viable option for tenure security is group/communal ownership (Ntsebeza 1999). McCusker details the failure of CPA to empower or enhance livelihoods among rural poor in the Limpopo Province (McCusker 2002). Lyne and Darroch explain that in late 2000 the Minister of Agriculture and Land Affairs understood the failure of SLAG to produce large results and consequently proposed a new plan (Lyne and Darroch 2003). The new plan, Land Redistribution for Agricultural Development (LRAD) permitted farmers above the set poverty level (of household income less than or equal to R1,500 per month) to obtain grants of up to R100,000.

The policies explained so far in this paper focus almost entirely on the Department of Land Affairs and not on the Department of Housing. The Department of Housing can take a stronger role in land use issues by claiming a major stake in the responsible growth of housing. A major strategic plan for the Department of Housing is to "develop and manage Sustainable Human Settlement Policies” (http://www.housing.gov.za/). Bannister explains how the Department of Housing has generally focused on urban housing issues and neglected rural communities; but both the Department of Land Affairs and the Department of Housing “are currently working to dispel this perception” (Bannister 2003). The role of the Department of Housing is not yet strong but remains a potential stakeholder. Political decisions made now will affect the implementation strategies for land reform and which government departments are required to oversee the implementation. 


\section{Section 3: Mankweng}

\section{Section 3.1: Geography of Mankweng}

Mankweng and surrounding communities, in the Limpopo Province, of South Africa are situated 30 kilometers east of Polokwane. The area is part of the former Lebowa homeland and is now part of the Polokwane Municipality. See figure 1.

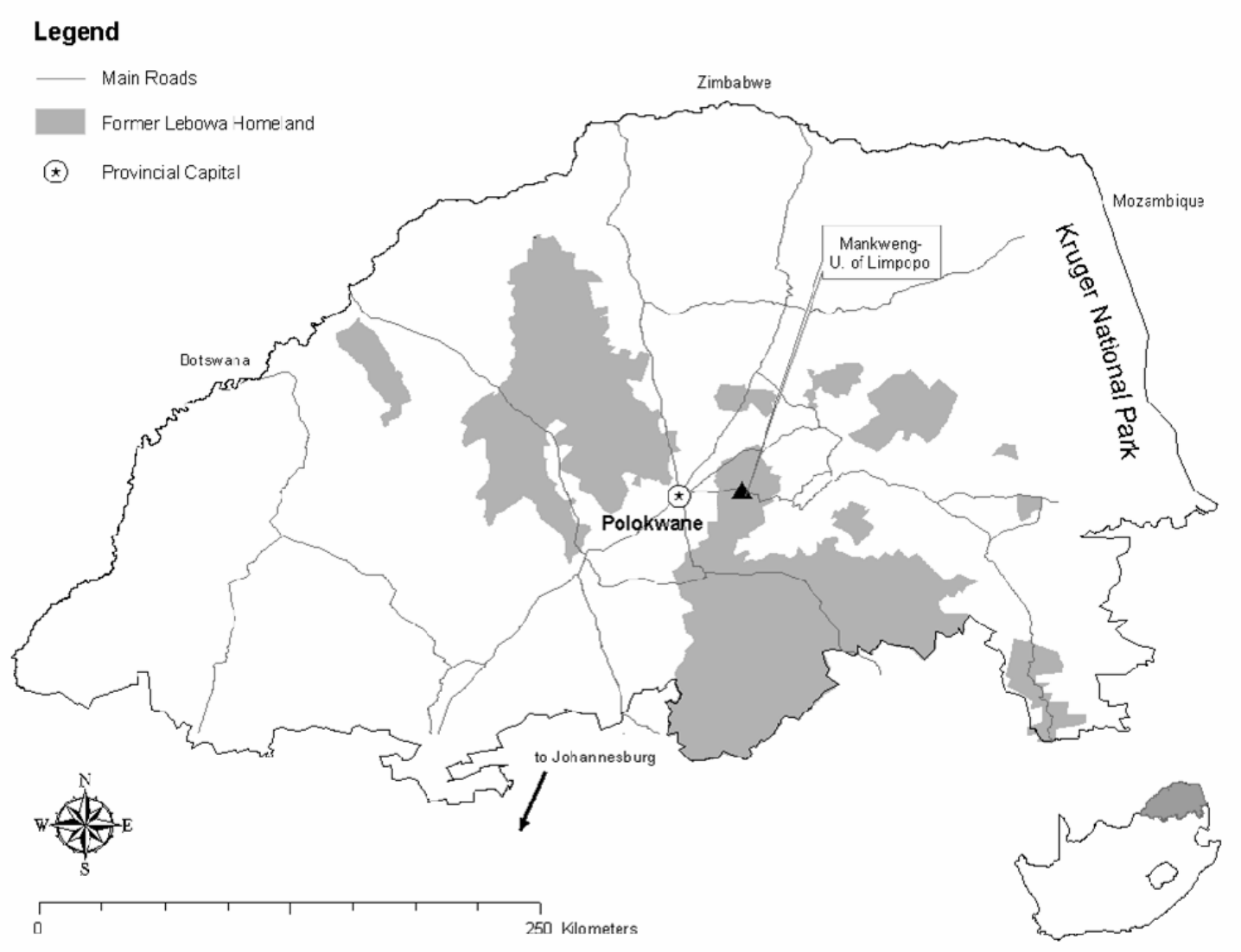

Figure 1: Map of Limpopo Province. Cartography by B. McCusker

Mankweng grew out of the population surrounding the University of the North. During the forced removals OF WHAT YEAR?, Africans were relocated from Pietersburg to Mankweng. The University of the North was founded in 1959 on a farm plot called Turfloop farm. Turfloop remains one of the popular “pet names” for the township. Commerce associated with the University began to grow and so did the Mankweng area. Eventually a major hospital was 
erected in the township. The region has steadily grown since its beginnings in the 1960's. Banks, shops and infrastructure have sprung up within the township center. However, many of the areas surrounding the University do not have municipal water or electricity. A local geographer describes the area:

The present Mankweng looks like a sprawling semi-urban settlement. The economic activities that are found in Mankweng are: shops and branches of banks (in the mall) and well as a forest of informal trading (mainly found next to the shops, along the streets and transport terminals). Many people who stay in urban Mankweng are public servants who work in the local schools, the hospital and the university.

The rural villages are less developed, with the inhabitants engaged in what might be regarded as below subsistence dry-land agriculture. Only few of the villages have basic services such as piped water (communal taps) along the streets and electricity. By law, the basic services are supposed to be supplied by the municipality; however, services in Mankweng villages are provided for by Eskom (electricity) and the Department of Water Affairs' (DWAF) subsidiaries. Where the above services are not provided for, communities get water from wells, fountains and sandy river beds. Fire-wood and kerosene (paraffin) are the main sources of energy. (Ramudzuli 2005)

This account relays the general economic conditions in the region. Other areas in South Africa clearly show the intention of the National Party to draw African area boundaries to serve the white community, and Mankweng illustrates the same issue at a larger scale. The area was convenient enough for white faculty and staff to commute from Pietersburg but far enough away from Pietersburg to buffer the city from campus demonstrations and uprisings. The population of the area continues to increase; yet more specific information about the motivations of people to live in Mankweng is not available. The creation of the University brought with it a draw of people, services, and economic opportunity. As the University grew, so did the population surrounding the University. Historically, the African National Congress used areas like Mankweng to gain a rural voting base by promising better services and access to more land. Area residents often comment that: soon I will have my own land to farm or members of my family will soon be getting land to farm. The realties of land tenure are still unclear. Later sections of this paper examine the politics of land use in Mankweng.

To better understand the land use changes in Mankweng, household surveys were conducted in 2005-6. This paper reports the methods and findings of research conducted on 
topics including: household interviews, key-informant interviews (including Academics and landowners) and governmental information.

\section{Section 3.2: Household Information}

The 2001 census of South Africa reports that 85.9 percent of Mankweng's (defined as Ward 25 of the Polokwane Municipality) ${ }^{1}$ of residents live in formal dwellings. The median household size is 4.95 . There has been a 38.3 percent increase in single resident households from 1996 to 2001. Number of rooms in each house varies from 1 to $10+$ with the mode number of rooms being 2 (SSA 2003). Aliber quantitatively details the impact of poor people in South Africa and goes on to explain the condition of rural areas: "for those people dwelling in former homeland areas that do not have access to arable land, that access can make a significant difference, though it does not often offer a route out of poverty. The tenuous link between chronic poverty and ultra-poverty discussed above, may largely be due to the fact that those with access to agricultural resources are less likely to become destitute, even though those resources are rarely sufficient to escape poverty altogether. However, land scarcity limits the number of people in rural areas who can derive these benefits” (Aliber 2003: 477).

In 2003, a Ward Profile, based on the Census of 2001, for all wards in the country was released by the Statistics South Africa (SSA 2003). The ward profile for Mankweng underscores the large growth within Mankweng. In 1996, there were 1605 formal households. This number increased to 4554 by 2001, a 183 percent increase. The informal dwellings also increased dramatically- from 575 in 1996 to 2001 in 2001 (a 248 percent increase). Figures 2 and 3 are graphs related to households in Mankweng. The information is derived from the 2001 census.

\footnotetext{
${ }^{1}$ While McCusker and Ramadzuli (Article in review) understand the Mankweng to be the core of a functional area; this paper defines Mankweng as Ward 25 of the Polokwane Municipality. Ward 25 is a political delineation by the Municipal Demarcation Board of South Africa. Support for Mankweng as a functional core of the region may be valid but boundaries are then difficult to draw because of scattered settlement on the periphery of the area. Land use change dynamics prevent a static boundary for this functional area. Since this paper demands specific population documentation, Ward 25 is only considered. Further research should be conducted to understand the functional area of Mankweng beyond political designations such as wards.
} 
Number of Rooms per House in Mankweng

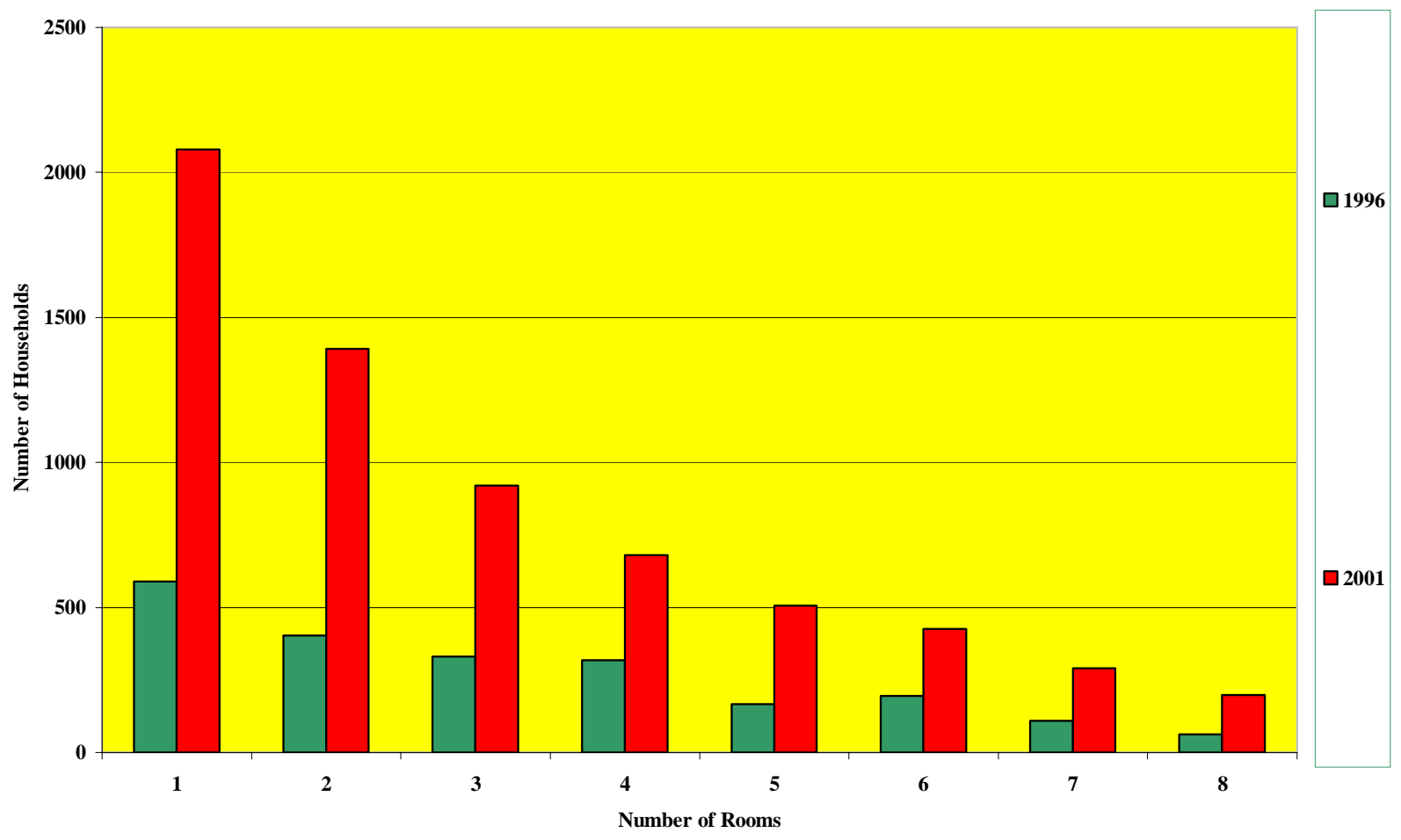

Figure 2: 2001 census data for Mankweng graphed by Author 
Number of People in each Household

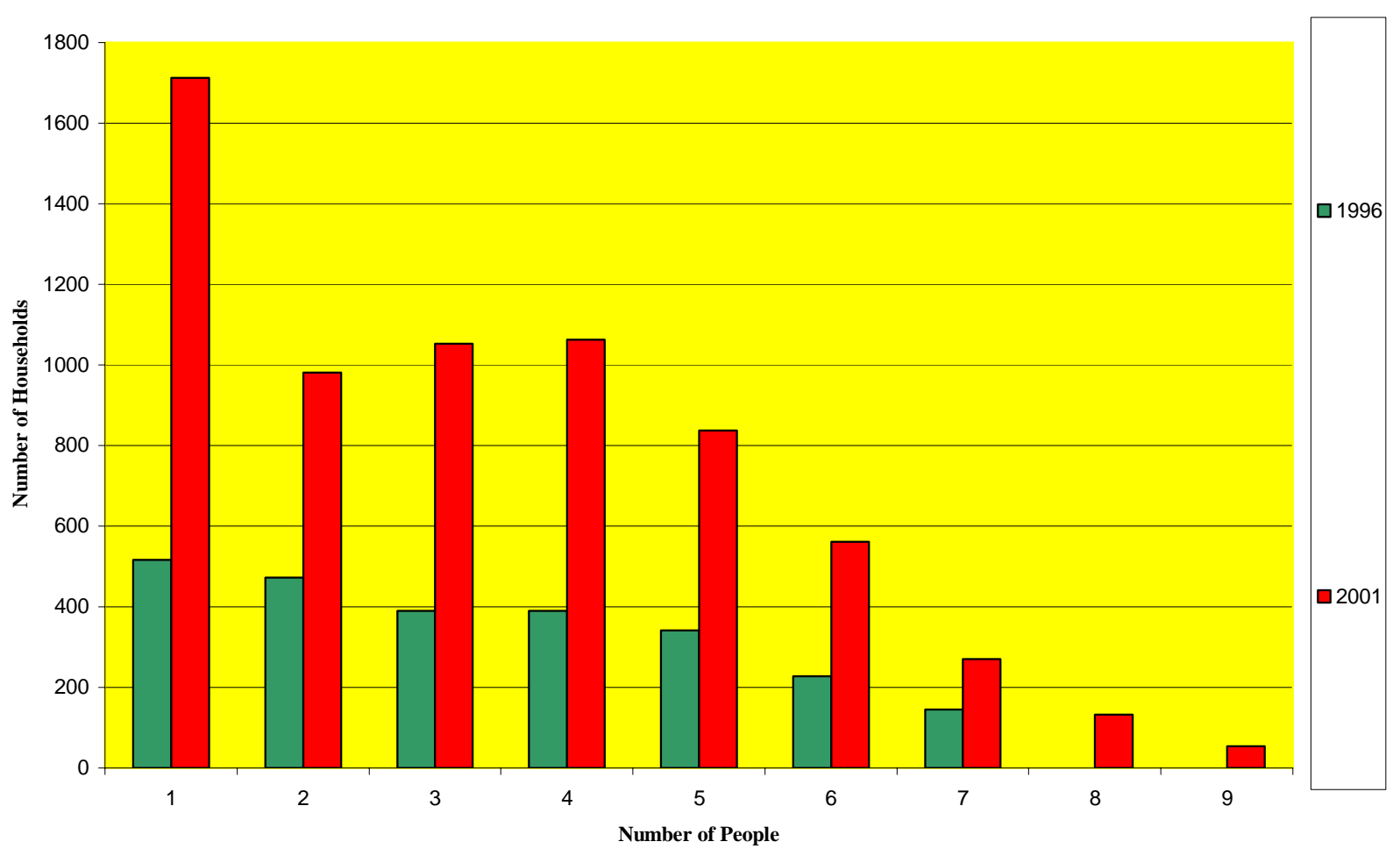

Figure 3: 2001 census data for Mankweng graphed by Author 


\section{Section 3.3: Land Use in Mankweng}

McCusker and Ramuduzli (McCusker and Ramadzuli Forthcoming) detail land use change in Mankweng. Their post-classification of aerial photography reveals the dramatic increase in household size plots surrounding the campus. Indeed, since 1963, household plots have doubled in area every ten years. Table 1 below shows the expansion of the area from 1963 to 1997. These figures represent a classification of Mankweng's entire functional region, the geographical extent of Mankweng reaches beyond the political lines of the township. This trend indicates the enormous pressure put on Mankweng by the surrounding area. As the table shows, the region is nearly doubling in size every ten years. As more households populate the area, less land is available for farming and more market space is demanded by the households. Indeed, complaints of local residents include the lack of proper markets or schools in the area. The surveys conducted for this paper heard households say: they must build a nice market in this area and children need to take taxis to get to school in the mornings.

Table 1 McCusker and Ramudzuli (Forthcoming) post-classification household analysis of the Mankweng Area

\begin{tabular}{|l|l|l|}
\hline Year & $\begin{array}{l}\text { Number of Structures } \\
\text { (houses + other buildings) }\end{array}$ & $\begin{array}{l}\text { Percentage } \\
\text { Increase (yr to yr) }\end{array}$ \\
\hline 1963 & 1074 & --- \\
\hline 1970 & 2208 & $105 \%$ \\
\hline 1981 & 4401 & $99 \%$ \\
\hline 1993 & 11727 & $166 \%$ \\
\hline 1997 & 16226 & $38 \%$ \\
\hline
\end{tabular}

\section{Section 3.4: History of the University of Limpopo}

Since Mankweng gradually built up around the University of the North, a brief history of the University is in order. The Extension of University Education Act of 1959 laid the foundation for the University of the North but the political groundwork had been thought out at least a decade before. The Tomlinson Report (U.G.61/1955 1955) “recommends that as speedily as possible a sufficient number of university colleges be established” and include a University 
serving "the Sotho speaking people of the Transvaal and Orange Free State” (U.G.61/1955 1955, p.202). Maps contained within the Tomlinson report name Turfloop as a major place name on a 1950 map issued by the government. Aerial photography for that area in the early 1950's reveal that no town or community existed. A local royalty who lived in the area and whose family rules the region was asked to recall his childhood. The respondent said the Turfloop farm was very "bushy with no families" living on the farm. Oftentimes, he would walk to the area with friends and hunt small animals. No villages existed there and the area was wild with little grazing.

In 1959, the University of the North was established to serve several apartheid contrived “ethnic groups” of Africans. Indeed, the local postal address, Sovenga, is a relic. The word Sovenga is an amalgamation of the three major "ethnicities" the University was to serve- the SOtho, VEnda and TonGA peoples. Aerial photography from 1963 indicates minimal land use in the area surrounding the University. Figure 4 shows the development in 1963.

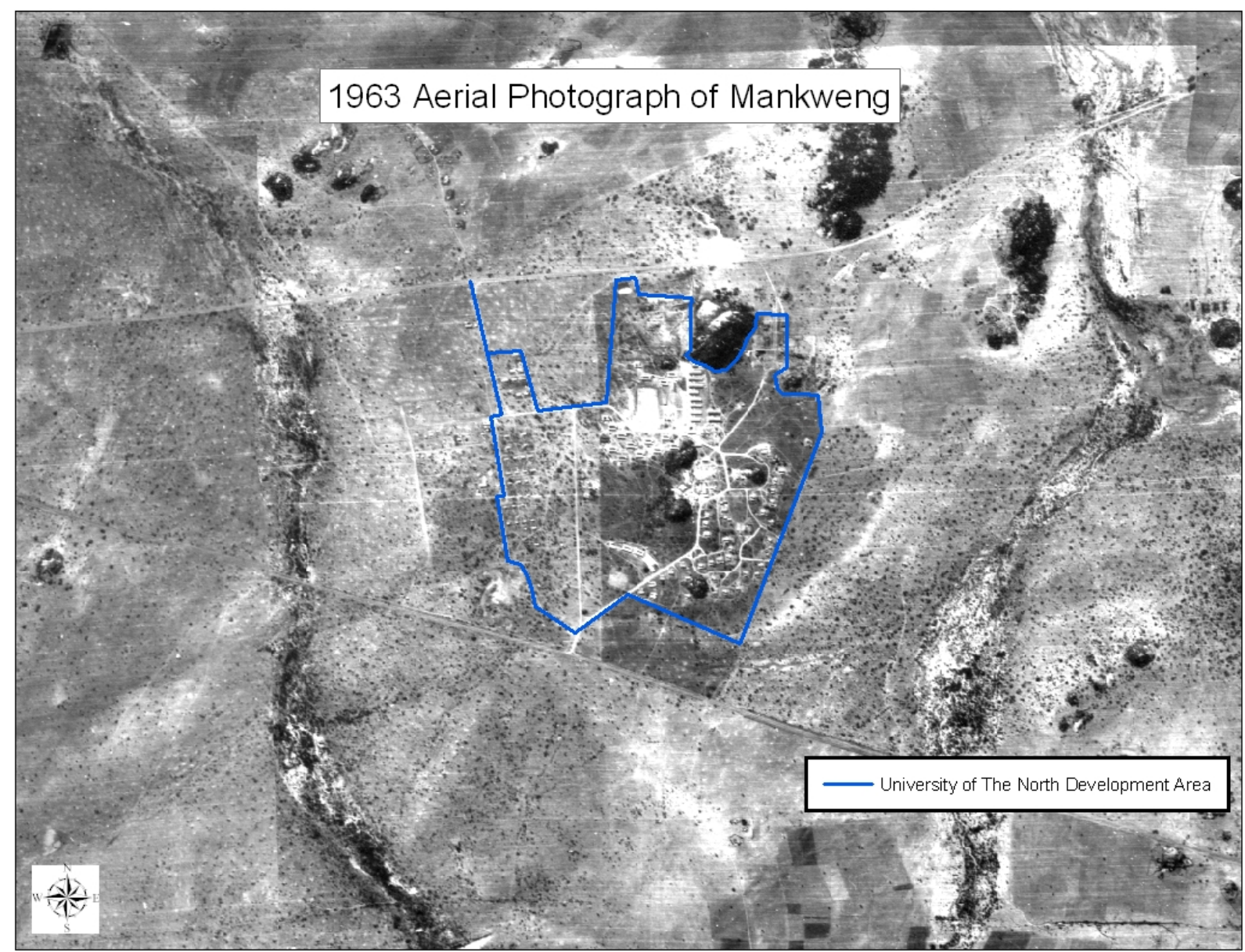

Figure 43 University of the North in 1963 
Housing units for both white and African staff were situated around the campus buildings. In 1977, the first African President of the University was appointed. Thereon, all Presidents (also known as Vice-Chancellors) were black. Since its inception, the University has served the African community and even today the campus is overwhelmingly African. In 2005, the campus joined with a Medunsa campus to form the University of Limpopo. While most buildings in the area immediately surrounding the campus compound have been either remodeled or reconstructed, some local houses remain from the 1950's. Figure 5 is an example of two such buildings in Unit A of Mankweng. African staff were housed in these small dwellings.

Neighbors of this house explain that inexpensive building materials meant that most houses have been remodeled or replaced.

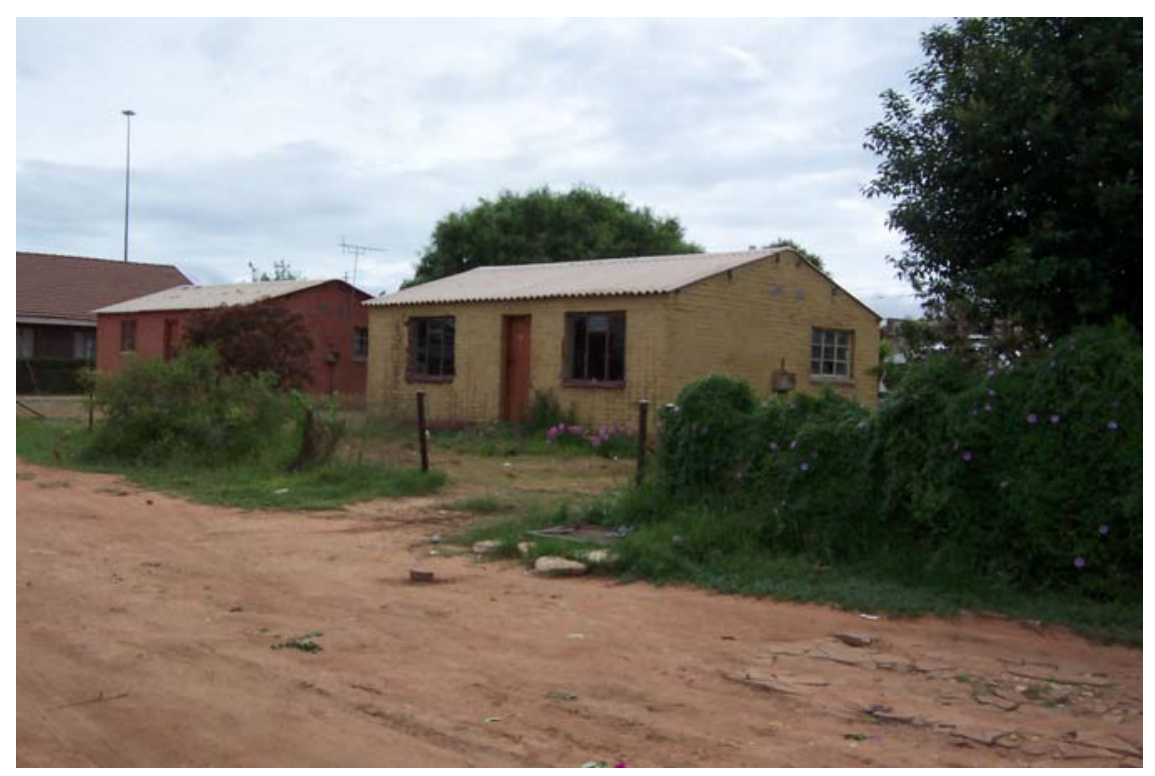

Figure 5: Mankweng housing built in the 1950's to house workers at the University of the North

Despite steady population growth since the 1950s, the area has seen local improvement only since the democratic elections of 1994. Indeed, many of the signs indicating service improvement in the area can still be seen. Figure 5 and 6 are examples of the signs standing long after projects were completed. 


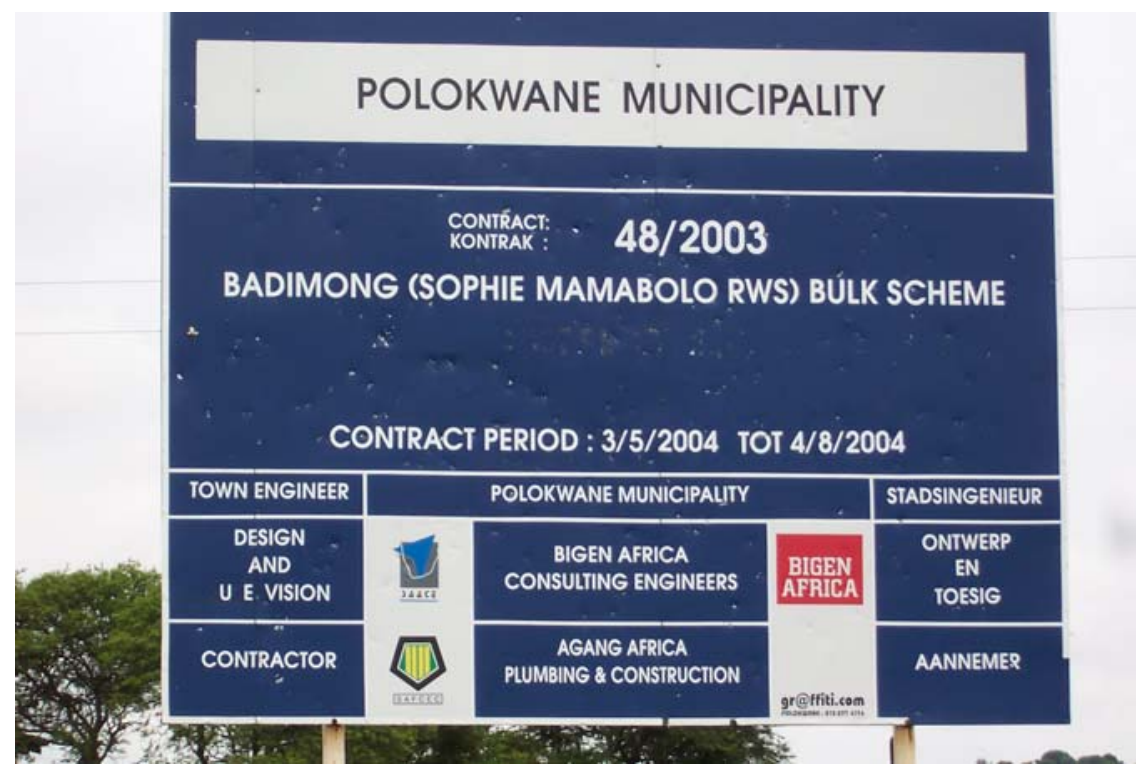

Figure 6: Government sign indicates current delivery of services. These signs pepper the Mankweng area.

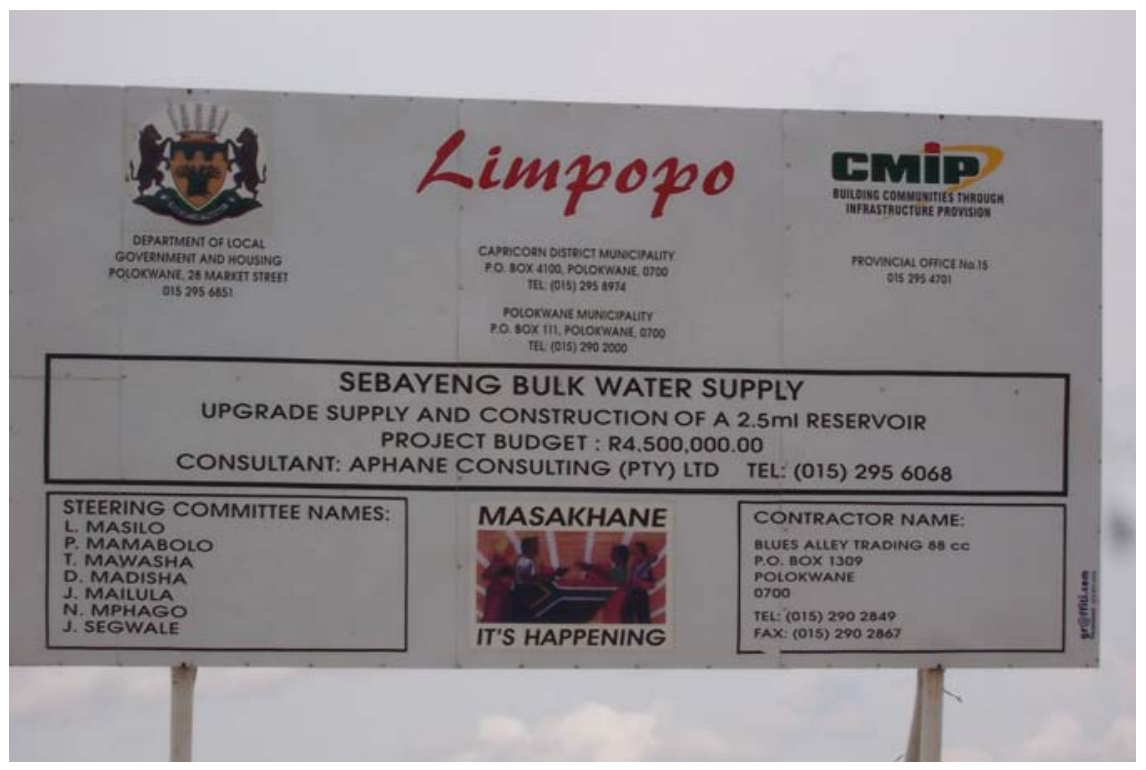

Figure 7: Provincial sign indicating delivery of services. 


\section{Section 4: Methods $^{2}$}

\section{Section 4.1: Household Interviews}

In December of 2005 and January of 2006, household surveys were conducted in Mankweng by the author. Financial constraints restricted a census in the area and, therefore, only two zoning sections of the town were chosen for the household surveys. Both zones have unique aspects. Zone A is the oldest part of town and includes housing structures built in the late 1950s and 1960s. This area provided many interviews of elderly people who had lived in the area since the early 1960s. Zone $\mathrm{C}$ is rapidly increasing in population and is one of the newer parts of Mankweng ${ }^{3}$. This area is primarily composed of immigrating families from other parts of South Africa. This zone was chosen to provide different information in comparison with Zone A. The initial intent of the interviews was to incorporate aerial photo interpretation into the survey. Four 34” x 44” aerial photographs from 1963, 1981, 1993, and 1997 were brought to the household. Respondents were asked questions about the photos. Unfortunately, orientation to the maps was difficult for the respondents. By the fifth survey it became clear photo interpretation would not be a viable part of the interviews. Nevertheless, questions in the survey could still be asked in absence of the aerial photos.

Forty-two household interviews were conducted in December 2005 and January 2006. Each interview lasted from 10 to 45 minutes depending on the details of the responses. A native Sepedi (Northern Sotho) speaking interpreter accompanied all interviews. The majority of respondents preferred to answer in Sepedi and were read the Institutional Review Board statement in Sepedi.

\section{Section 4.2: Sampling Framework}

Surveys could only be conducted in morning to mid-afternoon hours due to lower crime incidence during these times. During the daytime however, most men were not available for

\footnotetext{
${ }^{2}$ The research was approved for exemption from Institutional Review Board (IRB) review by the Eberly College of Arts and Science. See Appendix A and B for supporting documents.

${ }^{3}$ As mentioned in section 3.2 of this paper, Mankweng may be defined in different ways. Here, the political boundaries of Mankweng as demarcated by the Polokwane Municipality are used.
} 
comment and thus, the primary woman of the household answered most surveys. Upon entering Zone A or C, houses were chosen by availability. If no one answered the door, the house was passed by and the next house was solicited. No effort was given to revisit absent houses. This created two obvious but unavoidable problems. First, only people who were home in the daytime could respond to questions. This problem is ameliorated because any available household member could act as representative of the household and the questionnaires inquired about household intentions rather than the individual respondent's thoughts. The second problem is the lack of a stratified random sampling strategy. This prevents a comprehensive spatial analysis of the two zones.

\section{Section 4.3: Government reports and documents}

Obtaining government reports and documents about the area was difficult. Local government offices were reluctant to provide information. This may be because they did not

have the proper records or were wary of supplying sensitive information to non-government persons. Regardless of the reasons, little documentation could be obtained. Local council members, municipality official and provincial offices were all contacted for information but none provided useful information. The holiday season restricted access to many people since they were visiting family members and unavailable for consultation.

\section{Section 4.4: University of Limpopo Libraries}

The University of Limpopo, Turfloop Campus, has an archive of theses and dissertations. The papers in the archive provided some background on the Limpopo province but afforded no direct information about Mankweng. Key informants within the University of Limpopo did, however, detail the University's history. 


\section{Section 5: Data analysis and Findings}

\section{Section 5.1: Data analysis and Findings}

The forty-two surveys were analyzed for simple statistics. The small sample size makes more in-depth statistical analysis difficult and the research questions do not demand such computation. Two main sections of the survey served different purposes. The first part demanded simple responses from the respondent, e.g. what is your age? The second part contained open-ended questions which required more elaborate explanations. This section recounts and analyzes the responses from both sections.

Part one of the survey inquired about the general makeup of the household and certain descriptions of the respondent. Some of the questions included "where and when you born," “what is your household size?” and “who gave you permission to live here?” The majority of respondents were female (69\%); this may be explained by the time of day the surveys were conducted. Most respondents were born outside of Mankweng (93\%); this may be, in part, because the median age of the respondent is 49.5 years. Nearly all respondents received permission to live in the area by some government official, e.g. Superintendent, Magistrate, and Municipality. Permission of land rights is important considering the history of the area. As Mankweng was contained within the Lebowa homeland, tribal authorities permitted dwelling cites to citizens until the end of Apartheid. The terms Superintendent, Commissioner and Magistrate may have been used to describe the same authority. An initial conclusion on this might assume households have little understanding of the administrative processes involved in obtaining permission to live on a plot of land. This is wrong. The process of obtaining permission to live on a plot of land is more complex to people living outside the area than to those living in the households who obtain the permits. Permission To Occupy certificates are outdated, and have yet to be reformed. Consequently these certificates have retained legacies from previous laws. This may be seen on the national level when efforts to exclude local Chiefs from Permission To Occupy certificates were vehemently opposed by local authorities and were consequently deserted in the late 1990s (Lahiff 2003). For example, the Mankweng area, even though technically part of the Polokwane Municipality, is often influenced by the local Chiefdom 
(Mamabolo). Permission To Occupy certificates may still originate from the Chief, a legacy of the Homeland Authority Act of 1951. The median household size of respondents is 4.95 people, which concurs with the South African census data released in 2003. Only one household interviewed maintained a garden plot on the premises when they arrived in Mankweng and that household has since ceased to farm that land. Presently, some of the respondents do maintain garden plots but solely as recreation in their retirement years. When asked about their current income, most people could not reply because no one in the household had an income. Of the twelve respondents who did have an income, half said they made more money now than when they moved to Mankweng and half said they make less than when they moved here.

Part two of the survey probed for more in-depth information. These questions required more thought on the respondent's part and thus took up the majority of the interview. Replies were advantageous because they offered personal insight into the land use of the area. Example questions from this section include:

- Would you please recall this area when you moved here?

- Were there many houses?

- Did you receive the same services as you do now?

- How has this area changed?

These questions permitted the respondent to talk freely about the land use in the area. Many of the responses are included throughout this paper. The responses illustrate many local concerns about the land reform, land use, and the interaction between themselves, the government and others.

Replies to the questions about services and government responses depended on the zone. Zone A- the oldest part of town- had less commentary about future services. People living in this area would say things such as: we did not have electricity or water when we came here, we had to connect water from the street taps to the house and we were responsible for hooking up the services to our house. Zone C- one of the newer additions of Mankweng- talked more about future development: more tar roads should be in this area, more complexes (small marker areas) are needed, and everything seems to be improving annually.

These comments shed light on the movements of people to the area. As discussed earlier, the different political zones of Mankweng were settled at different times. The different comments in the different zones indicate people are looking to the future in different ways. 
The main findings of this survey highlight the broad spectrum of Africans moving to and living in Mankweng. Mankweng is experiencing rapid growth but not from any particular age group. However, household income tends to play an important role in land use of the area. Increasing development is not at the fast pace local people desire. Markets and transportation routes are essential to this peri-urban area but are not being adequately supplied. Households tend to favor more development because they want the urban-related services. A census or more comprehensive survey should be undertaken in order to more accurately gauge household opinion of the area.

The legacy of the Apartheid government in Mankweng's current land use became evident throughout this survey. While the African National Congress has worked to placate many households in Mankweng by bringing more services to the area, the ANC has only improved upon the same constructs that existed during the Apartheid government in Mankweng. That is to say, both the current and former government brought just enough services to keep the local community from uprising against the lack of expected services; but, neither the former nor the current government strategized a comprehensive program for eradicating ills produced by poor land use practices. The creation of Black elite in the area was seen during the Apartheid government and is also evidenced in today's democratic government. The survey conducted for this paper showed that households generally are not satisfied with the service any more now than they were when the Apartheid government was in power. This is not to say the households preferred the Apartheid government but rather to point out the paradigm of land use in Mankweng has not changed since the Apartheid era.

Future politics must focus on strategies to resolve delivery of service issues to Mankweng without resorting to the creation of issues similar to those of the nearby neighbor, Zimbabwe. Land use offers keen insight into how households are adapting to lack of services. This household survey indicates the need for a paradigm shift in the way services are delivered and the underlying intentions of those services. 


\section{Section 5.2: Recommendations}

Household surveys offer a unique perspective into land use in Mankweng. The ability to forecast future trends in land use is a valuable tool for stakeholders and government officials concerned with the area. This section offers three recommendations.

1. Better political voice of citizens to national government. Government allocation of funds to this area is essential for future stability in the area. The legacy of homeland inequities has illserved this area. Yet, the University offers hope for the area's future and maintains a beacon of employment and other social benefits.

2. More sound outlooks into the future by planning for the area. A comprehensive GIS should be implemented in the area. Full geographic inventories should be conducted in order to understand the change taking place in the area. This would also allow for better marketing of stores and petrol stations. The newest additions of markets in the Mankweng area are located in poorly thought-out sites as they disturb traffic on R-71- which poses a hazard to both pedestrians and drivers. GIS offers the capacity to plan the area in a more sound way by documenting past, current and potential future trends of growth.

3. A comprehensive transportation GIS can document and predict change in the area. The Mankweng area, as documented in this paper and others, has experienced growth since its beginnings. The Polokwane Municipality is currently undergoing a transformation to a government regulated taxi system. This transformation offers a unique documentation of population dynamics. If the Municipality is able to properly track the taxi systems through a robust GIS, the resulting information will offer government officials, stakeholders, and researchers insight to this dynamic area. Charting transportation patterns in this area might explain the regional fluctuations in population and movement of goods. Transportation GIS are capable of documenting transportation flows in real time. This timeline offers a view of current change. 


\section{Section 6: Summary and Conclusion}

The main objective of this thesis was to document local and national scale pressures on the land use of Mankweng, South Africa. This objective was accomplished by household survey, historical review and literature review.

Household surveys offer a local perspective to local phenomena. The surveys conducted for this thesis offer a glimpse into the complexities of the area. More detailed, in-depth interviews are required to obtain complete understanding of households in the area. Yet, the household surveys still provide valuable knowledge. Specifically, the surveys answer questions about the residents of Mankweng, why they came to Mankweng and how they feel about living in the area.

Past legislative acts and other historical events explain many of the present constraint on the local community. Understanding land use related legislation permits investigators to understand the development of the area through time. Many of the current issues facing Mankweng have roots in the past.

Finally, political ecology, as reviewed in Section 1, lays a framework to investigate human-environment interactions. In order to understand land use phenomena from a holistic standpoint, political ecology looks to the interaction of politics and land use. The political ecology literature supports the investigative tools used in this thesis.

\section{Conclusion:}

This thesis uses political ecology to frame the land use changes occurring in Mankweng, South Africa. By understanding how land use in Mankweng has evolved in the past fifty years, estimations about the future are possible. Household surveys underscore many of the changing views local residents have about Mankweng. These surveys also outline the need to document these changes as they occur so that future problems may be avoided. 


\section{Works Cited}

Al-Bakri J., J. Taylor, and T. Brewer. 2001. Monitoring land use change in the Badia transition zone in Jordan using aerial photography and satellite imagery. The Geographical Journal 167 (3): 248-262

Aliber, M. 2003. Chronic Poverty in South Africa: Incidence, Causes and Policies. World Development 31(3): 473-490.

Bannister, S. 2003. 6-Rural Settlement. Evaluating Land and Agrarian Reform in South Africa: An Occasional Paper Series. Cape Town: South Africa. Programme for Land and Agrarian Studies.

Batterbury, S. 2001. Landscapes of Diversity: A Local Political Ecology of Livelihood Diversification in South-Western Niger. Ecumene 8 (1): 437-464.

Blaikie, P. 1999. A Review of Political Ecology; issues, epistemology and analytical narratives. Zeitschrift fur Wirschaftsgeogrphie 43(3/4): 131-147.

Bouvier, L. and L. Grant. 1994. How many Americans? Population, Immigration and the Environment. San Francisco: Sierra Club Books.

Bryant, R. and S. Bailey. 1997. Third World Political Ecology. London: Routledge.

Bryant, R. 1998. Power, knowledge and political ecology in the third world: a review. Progress in Human Geography 22(1): 79-94.

Clark, N. and W. Worger. 2004. South Africa: The Rise and Fall of Apartheid. Harlow: Pearson Longman.

Development Report 2005. Reflections on the origins of poverty in South Africa Overcoming Underdevelopment in South Africa's Second Economy. Ed. Development Bank of Southern Africa. http://www.dbsa.org (last accessed 2 May 2006).

Fairhead, J. and M. Leach. 1996. Forest Gain: Historical Evidence of Vegetation Change. In Misreading the African Landscape: Society and Ecology in a Forest-Savanna Mosaic, eds. J. Fairhead and M. Leach, 55-85. Cambridge: Cambridge University Press.

Gray, L. 1999). Is Land Being Degraded? A Multi-Scale Investigation of Landscape Change in Southwestern Burkina Faso. Land Degradation and Development 10: 329343.

Lahiff, E. 2001. Policy Brief: Debating land reform and rural development. Land reform in South Africa: Is It Meeting the Challenge? Programme for Land and Agrarian Studies 1.

Lahiff, E. 2003. The Politics of Land Reform in Southern Africa. Sustainable Livelihoods in Southern Africa- Research Paper 19. Research Paper Series: Sustainable Livelihoods in Southern Africa: Institutions, Governance and Policy Processes.

Lahiff, E. and I. Scoones. 2001. Sustainable Livelihood in Southern Africa: Land Theme Research Briefing 1. The Politics of Land reform in Southern Africa: United Kingdom's Department for International Development: 1-4.

Lambin, E. 2003. Linking Socioeconomic and Remote Sensing Data at the Community and Household Level. In People and the Environment: Approaches by Linking Household and Community Surveys to Remote Sensing and GIS. eds. J. Fox, R. R. Rindfuss, S. J. Walsh and V. Mishra, 223-240. Boston, Dordrecht.

Lyne, M. and M. Darroch. 2003. Land Redistribution in South Africa: Part Performance and Future Policy. Department of Agriculture and Applied Economics, University of Wisconsin at Madison. http://www.basis.wisc.edu (last accessed 24 April 2006). 
Manji, A. 2001. Land Reform in the Shadow of the State: The Implementation of New Land Laws in Sub-Saharan Africa. Third World Quarterly 22(3): 327-342.

Mather, C. 2002. The Changing Face of Land Reform in Post-Apartheid South Africa. Geography 87(4): 345-354.

May, J. 2000. Monitoring the Impact of Land Reform on Quality of Life: A South African Case Study. Working Paper No. 31, Centre for the study of Developing Societies.

McCusker, B. 2002. The Impact of Membership in Communal Property Associations on Livelihoods in the Northern Province, South Africa. GeoJournal 56(2): 113-122.

McCusker, B. and M. Ramadzuli. Forthcoming. Peri-urbanization in Mankweng South Africa: Historical Political Ecologies of Land Use Change 1963-2001. p. 1-30.

Narsiah, S. 2000. Neoliberalism and Privatization in South Africa. GeoJournal 57: 3-13.

Ntsebeza, L. 1999. Land Tenure reform in South Africa: An Example from the eastern Caper Province. The DFID workshop on Land Rights and Sustainable Development in subSaharan Africa at Sunningdale Park Conference Centre, Berkshire, United Kingdom.

Page, B. 2003. The Political Ecology of Prunus africana in Cameroon. Royal Geographical Society. 35(4): 357-370.

Peet, R. and M. Watts. 1996. Liberation Ecologies: Environment, Development, Social Movements. New York: Routledge.

Platsky, L. and C. Walker. 1985. The Surplus People: Forced Removals in South Africa. Johannesburg: Raven Press.

Ramudzuli, R. 2005. Mankweng and its Environs. Personal communication with author. Mankweng, South Africa.

Rindfuss, R. and P. Stern. 1998. Linking Remote Sensing and Social Science: The Need and the Challenges. In People and Pixels: Linking Remote Sensing and Social Science. eds. D. Liverman, E. Moran, R. Rindufss and P. Stern, 1-27. Washington D.C.: National Academy Press.

Robbins, P. 2004. Political Ecology. Malden, USA: Blackwell.

Schroeder, R. 1999. Geographies of Environmental Intervention in Africa. Progress in Human Geography 23(3): 359-378.

SSA, S. S. A. 2003. Ward Profiles from 2001 Census. Statistics South Africa. http://www.statssa.gov.za (last accessed 9 May 2006).

Stott, P. and S. Sullivan. 2000. Political Ecology: Science Myth and Power. London: Arnold.

R. Sussman, G. Green, and L. Sussman. 1994. Satellite Imagery, Human Ecology, Anthropology, and Deforestation in Madagascar. Human Ecology 22(3): 333 - 354.

Turner, M. 2003. Critical Reflections on the Use of Remote Sensing and GIS Technologies in Human Ecological Research. Human Ecology 31(2): 177-182.

Turner, M. 2003. Methodological Reflections on the Use of Remote Sensing and Geographic Information Science in Human Ecological Research. Human Ecology 31 (2): 255-279.

U.G.61/1955. 1955. Commission for the Socio-Economic Development of the Bantu Areas: Summary of the report. Pretoria, South Africa: Government Printer: 1-213.

Vayda, A. and B. Walters. 1999. Against Political Ecology. Human Ecology 27(1): 167-179.

Warren, A., S. Batterbury, et al. (2000). Soil Erosion in the West African Sahel: a Review and an Application of a 'Local Political Ecology' Approach in South West Niger. Global Environmental Change 11: 79-95. 
Zimmerer, K. 2004. Cultural Ecology: Placing Households in Human-Environment Studies - the Cases of Tropical Forest Transitions and Agrobiodiversity Change. Progress in Human Geography 28(6): 795-806.

http://www.housing.gov.za/. Republic of South Africa: Department of Housing (last accessed on $5 / 2 / 06)$. 


\section{Appendix A: Respondent Handout}

\section{WestVirginiaUniversity}

Eberly College of Arts and Sciences

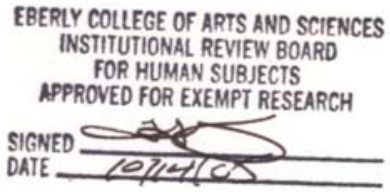

Dear Respondant,

Thank you for taking the time to answer the following questions. The purpose of this questionnaire is to better understand the driving forces of land use change in the Mankweng area. This research is being conducted as part of my Master thesis research at West Virginia University. Your answers to the questions will be kept anonymous. Your name and specific geographic location will not be recorded. You do not have to answer any questions you do not want to answer. Your class standing or job status will not be affected by refusal to participate or withdrawal from the study. Filling out this questionnaire is voluntary and you may choose to end the interview at any time without incident.

Thank you for taking the time to speak with me. If you have further questions or concerns, I may be contacted by postal mail or email (information provided below).

Sincerely,

Joshua Rutkowski

425 White Hall

P.O. Box 6300

Morgantown, WV, USA 26506

jrutkow5@mix.wvu.edu 


\section{Appendix B}

\section{WestVirginiaUniversity}

Eberly College of Arts and Sciences

\section{MEMORANDUM}

TO: Joshua Rutkowski

Department of Geology and Geography

FROM: $\quad$ Fred L. King /

Associate Dean ior v (yorn

Research and Graduate Studies

DATE: $\quad$ October 17, 2005

RE: Application for Exemption from Institutional Review Board

I have reviewed your application for exemption from IRB review and agree that "Understanding Land Use Change in Mankweng, South Africa Through Social Survey and Geographic Information" qualifies for exemption status. Accordingly, you may begin your research. As you do so, be sure that you follow those IRB procedures and guidelines necessary for protecting the subjects of your research.

Please let me know if I can provide any additional assistance or information. Good luck with your research.

cc: Trevor Harris, Chair

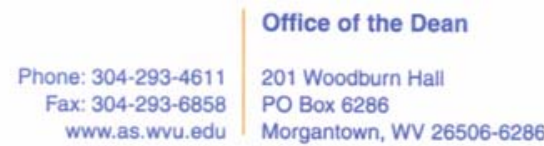

Equal Opportunity/Affirmative Action Institution 